\title{
PERSAHABATAN: MAKNA DAN KONTRIBUSINYA BAGI KEBAHAGIAAN DAN KESEHATAN LANSIA
}

\author{
Made Diah Lestari ${ }^{1}$ \\ Program Studi Psikologi \\ Fakultas Kedokteran \\ Universitas Udayana \\ Gedung FK Unud, J1. PB Sudirman \\ Denpasar, Bali 80232, Indonesia \\ ${ }^{1}$ e-mail: mdlestari@unud.ac.id
}

\begin{abstract}
Activity theory has given an enormous perspective on ageing with the concept of successful ageing. The theory views older people as an active, productive, and sociable group. Social contact or participation is one of the indicators of an ageing-friendly community which has been declared by World Health Organization. Maintaining friendship is an example of social contact in older people. The pattern of friendship changes according to the abilities and needs in every stages of human development. The aim of the study is to find the pattern of friendship, the meaning of friendship, and friendship impact on physical and psychological healthiness in older people. The participants were 14 older people from 64 to 70 years old. The present study is a qualitative research using photovoice method. According to participatory and coding analysis, the study has found several themes which contributed to the pattern of friendship, namely the definition of who friends are and the duration of companionship. For the participants, friend is appreciated as someone who become part of their memory, someone who always serve openness, and someone who gets them away from loneliness. Friendship was seen as a type of relationship which is built by pure interest. Friendship activities that benefit the older people are getting together with friends, sharing experiences, finding solutions to the problems encountered, visiting friends, attending important events of friends, running hobby, and doing physical activity. The critical findings of the present study can be used for planning the management model of healthcare for the older people.
\end{abstract}

Keywords: older people; friendship; photovoice.

\begin{abstract}
Abstrak - Activity theory telah memberikan perspektif yang baru dalam bidang gerontologi dengan konsep successful ageing. Teori ini menilai lanjut usia (lansia) sebagai kelompok yang aktif, produktif, dan masih mampu berkiprah dalam situasi sosial. Partisipasi sosial adalah salah satu indikator dari komunitas ramah lansia yang dideklarasikan oleh World Health Organization. Mampu menjaga persahabatan adalah salah satu dari bentuk kontak sosial dan partisipasi sosial bagi lansia. Pola-pola persahabatan berubah seiring dengan perkembangan usia seseorang. Tujuan dari penelitian ini adalah untuk melihat pola persahabatan, makna persahabatan, dan dampak persahabatan bagi kondisi fisik dan
\end{abstract}


psikologis lansia. Responden penelitian ini adalah 14 orang lansia yang berusia 64 hingga 70 tahun dan aktif mengikuti kegiatan bersama teman. Penelitian ini menggunakan metode kualitatif dengan photovoice. Melalui analisis partisipatori dan koding, studi mendapatkan tema-tema yang berkontribusi pada pola persahabatan lansia, seperti siapa yang dianggap sebagai teman, durasi persahabatan dan pertemanan. Bagi responden, teman adalah sosok yang merupakan bagian dari memori masa lalu, seseorang yang menghadirkan keterbukaan, dan mampu menjauhkan mereka dari rasa kesepian. Persahabatan dinilai sebagai bentuk hubungan yang dibangun dari intensi yang murni tanpa tendensi apa pun. Aktivitas bersama sahabat yang mampu memberikan dampak positif bagi responden adalah berbagai pengalaman, mengunjungi teman, menghadiri acara-acara penting sahabat, menjalankan hobby bersama, dan berolahraga. Hasil dari penelitian ini mampu menjadi dasar bagi penatalaksanaan kesehatan bagi lansia.

Kata Kunci: lansia; persahabatan; photovoice.

\section{PENDAHULUAN}

Proporsi pendudukan lanjut usia (lansia) meningkat dari tahun ke tahun. Proporsi penduduk lansia di Indonesia mengalami peningkatan hingga 9.7\% pada tahun 2011 (Badan Pusat Statistik (BPS), dalam Lestari, 2016). Proporsi ini diprediksi akan mengalami peningkatan $11.34 \%$ di tahun 2020 dan menjadi 25\% di tahun 2050. Indonesia menduduki peringkat ke-empat dunia sebagai negara dengan jumlah penduduk lansia tertinggi setelah Cina, India, dan Amerika Serikat. Data ini sekaligus menunjukkan peningkatan usia harapan hidup di Indonesia. Kondisi ini mengarahkan Indonesia ke era penduduk berstruktur tua atau yang dikenal dengan istilah ageing population (Suardiman, 2011).

Kondisi ini adalah cerminan dari suksesnya pembangunan di bidang kesehatan yang meliputi sistem dan infrastruktur di dalamnya serta peningkatan pengetahuan masyarakat tentang pentingnya kesehatan. Di sisi lain, jumlah pendudukan lansia yang meningkat juga menyumbang bagi angka tergantung hidup di suatu wilayah atau yang disebut dengan old dependency ratio. Kondisi ini melahirkan pandangan baru di bidang gerontologi. Fokusnya tidak lagi bagaimana memperpanjang usia dan harapan hidup, namun bagaimana membantu lansia tetap produktif dan mandiri di usia lanjut.

Kebahagiaan memberikan kontribusi yang besar bagi kemandirian lansia (Lestari, 2015). Kebahagiaan lansia berkorelasi dengan kualitas hubungan dan jumlah dukungan sosial serta interaksi dengan orang lain (Valliant, dalam Suardiman, 2011). Ada dua teori besar yang membahas mengenai konsep hubungan dan interaksi pada lansia. Teori pertama disampaikan oleh Cumming dan Henry 
(2016). Teori tersbeut dikenal dengan disengagement theory yang menyatakan bahwa ketika individu memasuki masa dewasa akhir, aktivitas dan sosialisasi mereka akan berkurang. Menurut teori ini successful ageing ditandai dengan pemisahan atau penarikan diri secara sosial dan meninggalkan peran sosial sedikit demi sedikit. Teori yang kedua disampaikan oleh Neugarten dkk. (dalam Suardiman, 2011) yang dikenal dengan activity theory. Teori ini memberikan perspektif yang berbeda terkait successful ageing. Sukses di masa tua berarti lansia tetap aktif, produkti, dan menjaga kehidupan sosialnya, selayaknya kondisi fisik dan emosional lansia.

Salah satu sumber dukungan sosial pada lansia adalah sahabat. Pola persahabatan berubah seiring dengan kemampuan dan kebutuhan di setiap tahapan perkembangan. Bagaimana anak-anak, remaja, dan orang dewasa memandang dan memberikan makna pada pertemanan atau persahabatan dapat jadi sangat berbeda dengan bagaimana pemaknaan lansia. Unsur penting dari persahabatan menjadi stabil, solid, dan lebih penting di usia lanjut. Berdasarkan activity theory, persahabatan memegang peranan penting dalam kehidupan lansia. Demir dan Ozdemir (2010) menemukan bahwa kualitas persahabatan adalah prediktor penting bagi kebahagiaan. Studi ini akan mendiskusikan persahabatan pada lansia dan bagaimana persahabatan berdampak pada kebahagiaan dan kesehatan. Bagaimana lansia memaknai persahabatan di usia lanjut mereka menjadi pertanyaan utama penelitian. Lebih lanjut, penelitian juga akan melihat bagaimana persahabatan mampu berkontribusi bagi kebahagiaan dan kesehatan di usia lanjut. Penelitian ini adalah penelitian kualitatif dengan menggunakan photovoice.

\section{METODE}

\section{Partisipan}

Responden dalam penelitian ini berjumlah 14 orang lansia di Denpasar, Bali, yang menjaga persahabatan mereka mulai dari masa sekolah hingga saat ini. Lansia ini rutin mengadakan pertemuan dan reuni dengan sahabat mereka setiap bulannya. Usia responden adalah 64-70 tahun.

\section{Desain}

Studi ini adalah studi kualitatif dengan menggunakan photovoice yang dipopulerkan oleh Wang dan Burris (dalam O’Grady, 2008). Dalam studi ini, media foto digunakan untuk mengidentifikasi dan mengkomunikasi makna, bentuk persahabatan di usia lanjut dan bagaimana persahabatan dapat 
meningkatkan kebahagiaan, kesejahteraan psikologis, dan kesehatan fisik. Identifikasi dilakukan oleh responden penelitian dengan mengambil foto yang sesuai dengan pertanyaan penelitian. Elisitasi foto kemudian dilakukan melalui wawancara mendalam dengan menggunakan SHOWED teknik yang terdiri dari lima pertanyaan, yakni, what do you SEE here, what's really HAPPENING here, how does this relate to OUR lives, why does this situation EXIST, dan what can we DO about it.

\section{Prosedur}

Penelitian diawali dengan program induksi kepada 14 responden. Program induksi ini bertujuan untuk memperkenalkan photovoice kepada responden dan memperkenalkan mekanisme pengambilan data dengan menggunakan photovoice. Setelah mengikuti program induksi, responden diminta untuk menyetujui terlebih dahulu informed consent dan mekanisme photovoice sebelum melakukan kegiatan photovoice. Responden kemudian diberikan waktu selama 1 minggu untuk mengumpulkan foto yang berkaitan dengan pertanyaan penelitian, yakni bagaimana makna persahabatan di usia lanjut, bagaimana bentuk persahabatan di usia lanjut, dan bagaimana persahabatan mampu meningkatkan kesejahteraan psikologis dan kesehatan fisik. Responden berhak mengambil foto yang berkaitan atau memilih foto dari koleksi pribadi mereka. Setelah 1 minggu, responden kemudian menyerahkan foto kepada peneliti dan dilanjutkan dengan focused group discussion, membuat narasi pada foto, dan wawancara mendalam dengan menggunakan SHOWED teknik.

\section{Teknik Analisis}

Data yang berupa foto dan narasi kemudian dianalisis dengan menggunakan analisis partisipatori dan coding. Analisis partisipatori berarti, responden penelitian memiliki kesempatan untuk memberikan makna pada foto yang mereka kumpulkan dan memberikan narasi yang tepat yang menggambarkan foto. Tahap selanjutnya, peneliti melakukan proses open coding, axial coding, dan selective coding berdasarkan pendekatan Strauss dan Corbin (1990) untuk menemukan tema-tema sentral yang berkaitan dengan makna dan arti persahabatan di usia lanjut. 
ANALISIS DAN HASIL

\section{Profil Responden}

Responden penelitian seluruhnya berdomisili di Denpasar. Sebanyak 14 responden saling mengenal satu sama lain dan secara rutin terlibat pertemuan minimal sebulan sekali. Komunikasi dengan sahabat biasanya dilakukan melalui telepon dan media sosial. Tabel 1 memperlihatkan karakteristik responden.

Tabel 1. Karakteristik responden

\begin{tabular}{llllll}
\hline No & Initial & Jenis Kelamin & Usia & Tinggal Bersama & Profesi \\
\hline 1 & KR & Perempuan & 70 Tahun & Pasangan dan anak & Pensiunan \\
2 & IN & Perempuan & 64 Tahun & Pasangan dan anak & Pegawai Negeri \\
3 & AT & Laki-laki & 65 Tahun & Pasangan dan anak & Pensiunan \\
4 & HN & Perempuan & 63 Tahun & Sendiri & Pegawai Negeri \\
5 & CH & Laki-laki & 64 Tahun & Pasangan & Wiraswasta \\
6 & SM & Laki-laki & 70 Tahun & Pasangan dan anak & Wiraswasta \\
7 & SD & Laki-laki & 64 Tahun & Pasangan & Pensiunan \\
8 & SB & Laki-laki & 64 Tahun & Pasangan dan anak & Pegawai Negeri \\
9 & RS & Laki-laki & 65 Tahun & Pasangan & Pensiunan \\
10 & SJ & Laki-laki & 65 Tahun & Pasangan & Pensiunan \\
11 & DP & Laki-laki & 64 Tahun & Pasangan dan anak & Wiraswasta \\
12 & KT & Perempuan & 64 Tahun & Pasangan dan anak & Ibu Rumah Tangga \\
13 & KS & Perempuan & 64 Tahun & Anak & Guru \\
14 & GA & Perempuan & 65 Tahun & Pasangan dan anak & Pensiunan \\
\hline
\end{tabular}




\section{Makna Persahabatan pada Lansia}

Partisipan melihat bahwa persahabatan di masa tua memiliki makna keterbukaan dan rasa percaya satu sama lain.

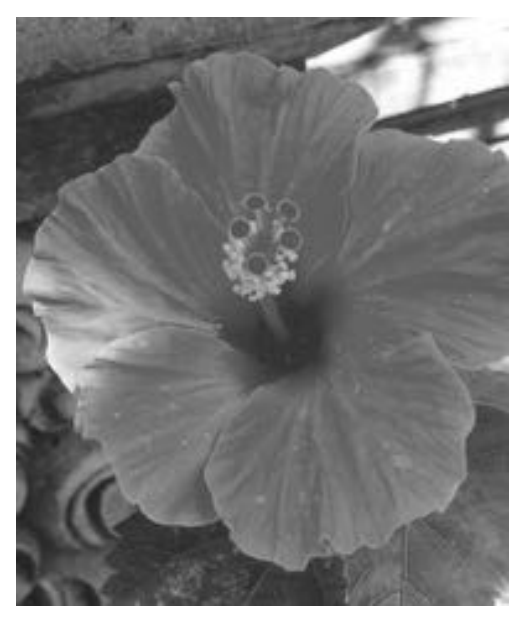

Gambar 1. Keterbukaan

"Saya melihat suatu keindahan yang mendasari keterbukaan ini. Yang sebenarnya terjadi adalah dalam diri yang bersih atau hati yang bersih, semuanya akan tampak indah. Suasana hati kita sangat menentukan. Semoga ini akan sangat berpengaruh kepada kehidupan sehari-hari. Situasi yang indah ini ada karena tekad kita untuk mengalahkan hati dan perasaan agat tetap bersih. Kita harus lebih banyak belajar melatih hati dalam usia sekarang ini. " (DP, 64 tahun)

Partisipan juga melihat bahwa persahabatan adalah suatu yang indah dan menyegarkan. Seperti layaknya bunga yang baru mekar dan memberikan manfaat bagi kehidupan mereka.

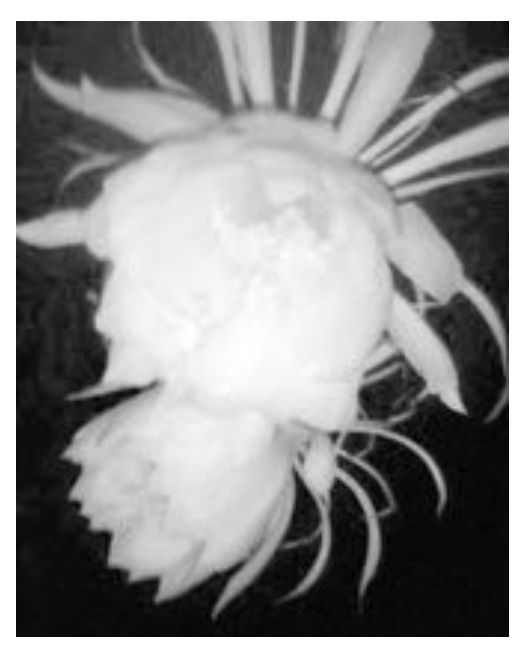

Gambar 2. Indah dan Segar

"Persahabatan itu indah, segar, dan putih bersih. Persahabatan yang didasari oleh jiwa yang bersih dan tidak ada maksud-maksud tertentu. Hingga saat ini seperti itulah makna persabahatan bagi saya." (AT, 65 tahun). 
Persahabatan juga memiliki makna sebuah hubungan yang erat dan terikat satu sama lain. Bagi partisipan, persahabatan adalah sebuah ikatan energi. Silaturahmi membangun hubungan yang terputus di masa lalu adalah bagian dari persahabatan di masa tua. Sahabat adalah bagian dari sejarah masa lalu.

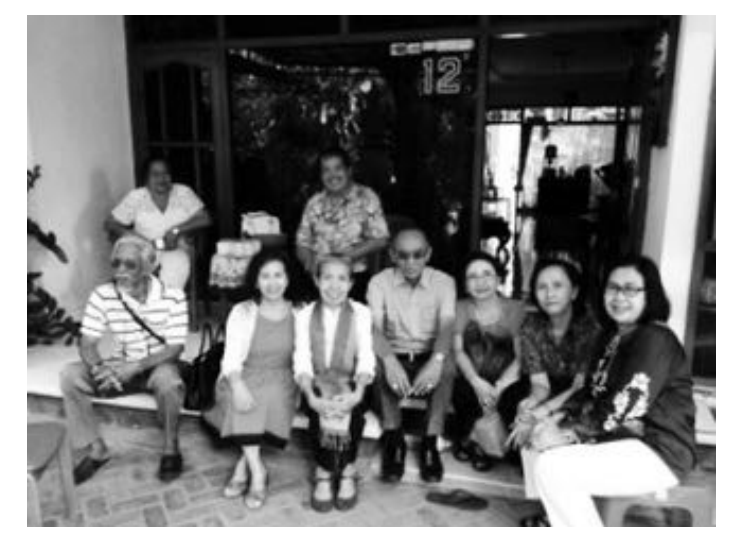

Gambar 3. Sahabat dan Kenangan Masa Lalu

"Persahabatan membuat saya mengenang masa lalu. Semakin semangat menjalani kehidupan. Bertemu dengan teman-teman membuat gairah hidup kembali lagi. Pertemuan selalu menyenangkan." (SJ, 65 tahun)

Sahabat mengandung makna seseorang yang mampu menghadirkan kehidupan yang jauh dari rasa sepi di masa tua. Persahabatan di usia lanjut mampu menghadirkan afeksi, kedekatan, perhatian, dan kebersamaan.

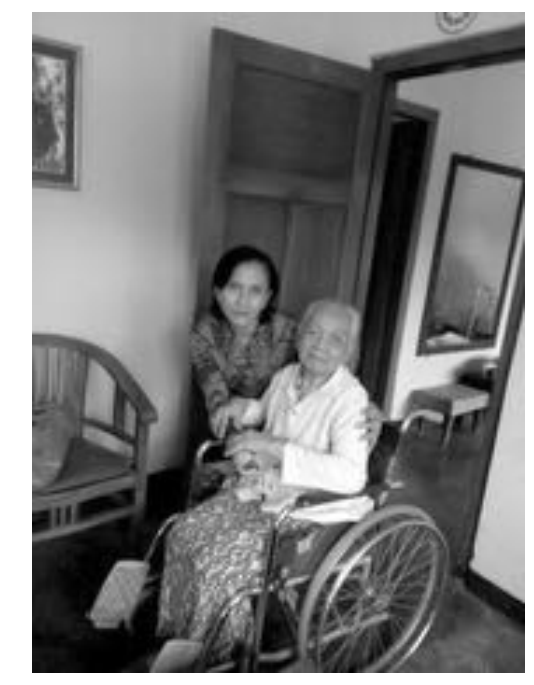

Gambar 4. Jauh dari Rasa Sepi

"Merasa bahwa semua akan tua dan kita ingin seperti ibu ini juga dijenguk dan diajak berkomunikasi. Masa tua akan jauh dari rasa sepi." (IN, 64 tahun) 
Persahabatan di masa tua mampu menghadirkan makna kebersamaan, kasih sayang, dan juga perhatian kepada orang-orang terdekat.

\section{Bentuk Persahabatan di Usia Lanjut}

Ada beberapa bentuk persahabatan di usia lanjut. Hasil menunjukkan bahwa bentuk persahabatan dapat dilihat dari siapa yang dimaksud dengan sahabat dan durasinya.

\section{$\underline{\text { Siapa yang dimaksud dengan sahabat }}$}

Persahabatan dipandang sebagai suatu yang universal. Persahabatan dibina dengan beragam orang, mulai dari teman di masa sekolah, keluarga teman, dengan generasi yang lebih muda, dan juga keluarga.

Persahabatan yang dibina sejak dahulu pada akhirnya berkembang tidak hanya dengan teman sekolah, namun juga keluarganya.

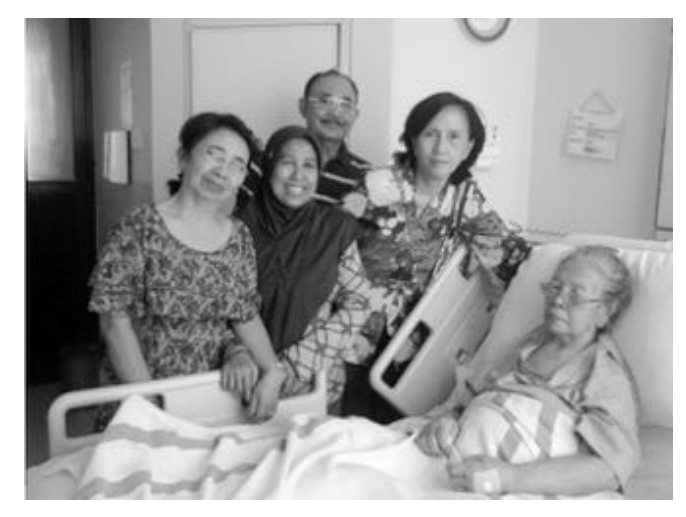

Gambar 5. Bersahabat dengan Keluarga Teman

"Persahabatan dengan banyak teman, Photo ini sedang menjenguk ibunya sahabat, Endang yang sedang sakit. Sangat bermanfaat demi kelangsungan persahabatan. Photo ini memperlihatkan persahabatan yang kekal. Akan selalu dipertahankan demi persahabatan yang berlanjut." (GA, 65 tahun) 
Usia juga tidak menghalangi seseorang untuk membangun persahabatan dengan generasi yang lebih muda.

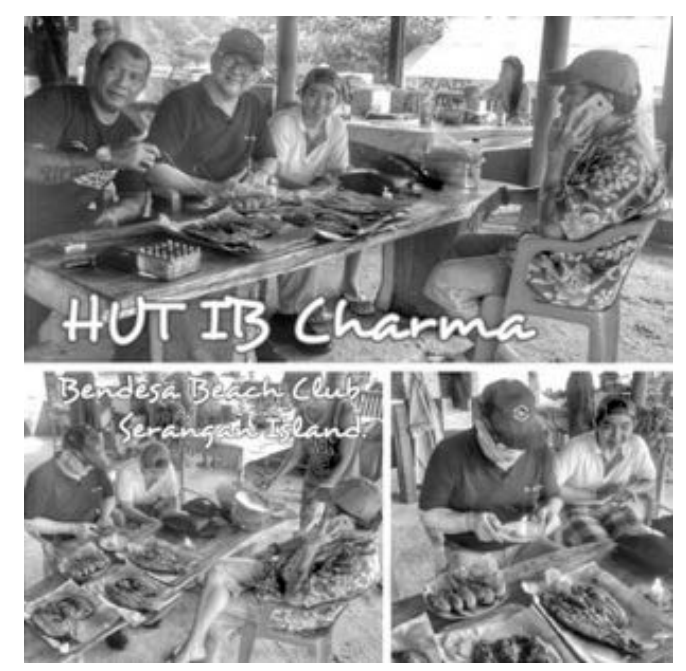

Gambar 6. Bersahabat dengan Yang Lebih Muda

"Sahabat di sekitar saya yang rata-rata pekerjaannya adalah nelayan dan umurnya lebih muda banyak memberikan inspirasi dan mereka sangat menghargai kehadiran kita yangjuga ingin didengar. Ini sangat erat dengan keinginan saya untuk membantu menyejahterakan mereka dengan jalan yang belum pernah mereka bayangkan. Ini terjadi karena pengalaman saya sebelumya yang membuat kepekaan menjadi tinggi, melihat situasi yang carut-marut dan saya akan mengerjakan untuk membantu menyelesaikan masalah mereka." (CH, 64 tahun)

Selain dengan teman. bersahabat dengan keluarga juga salah satu bentuk dari persahabatan di masa tua. Persahabatan dibina dengan istri, anak, dan juga cucu.

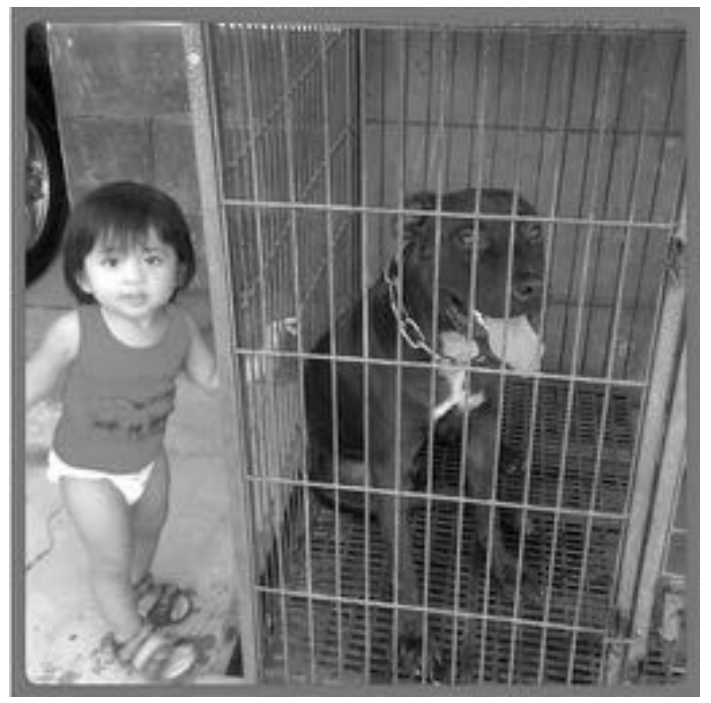

Gambar 7. Bersahabat dengan Keluarga 
"Persahabatan juga dibina dengan istri dan cucu. Mereka memberikan aspirasi dan menghibur saya. Merupakan sumber semangat hidup." (RS, 65 tahun).

\section{Durasi persahabatan di masa tua}

Persahabatan di usia lanjut dapat dibina dengan orang baru, maupun orang lama. Hubungan persahabatan yang dibina dengan orang lama, biasanya berasal dari teman-teman pada saat di bangku sekolah. Persahabatan berlangsung lama, semakin tua merasa bahwa persahabatan semakin kekal dan harmonis.

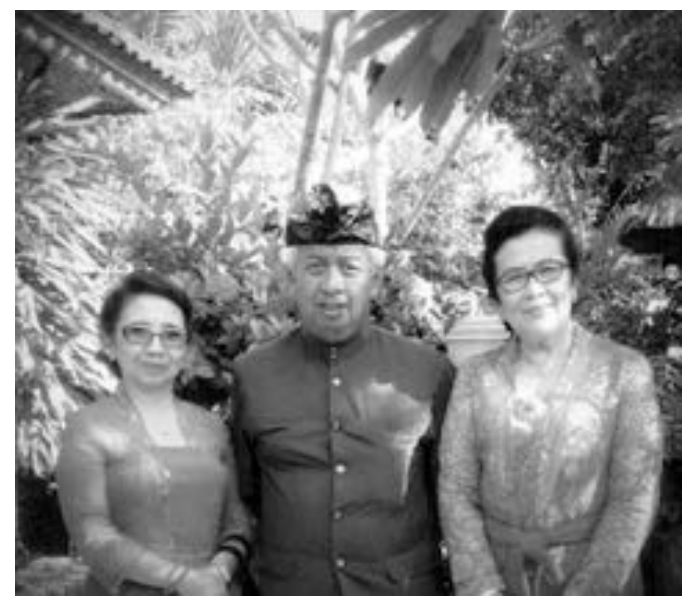

Gambar 8. Persahabatan yang Kekal

"Bersahabat dengan banyak teman, semakin harmonis, sangat bermanfaat bagi kelanggengan persahabatan. Photo ini memperlihatkan persahabatan yang kekal." (SB, 64 tahun).

Persahabatan yang berlangsung lama mengubah bentuk persahabatan yang mengarah kepada kekeluargaan. Sahabat dipandang sebagai bagian dari anggota keluarga. Anggota keluarga sahabat pun dianggap sebagai sahabat.

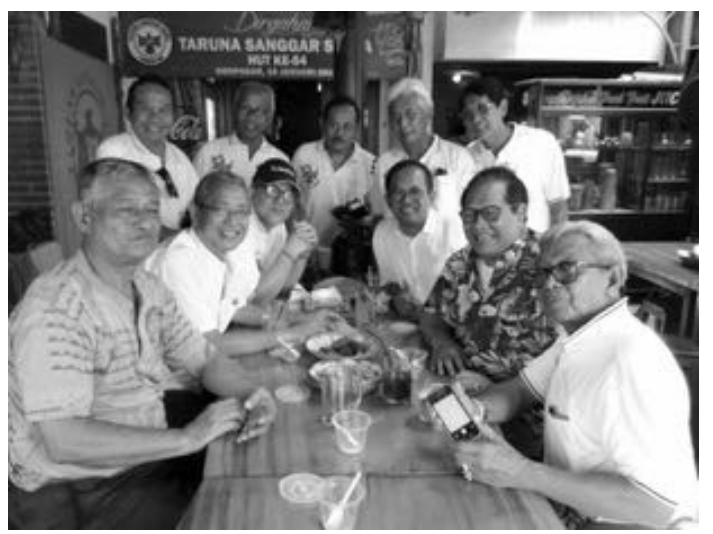

Gambar 9. Sahabat adalah Keluarga

"Di usia lanjut, kumpul bersama tersenyum bersama satu dengan yang lain. Saling mengingat kejadian berkesan di masa lalu. Terasa hidup di masa lalu. Persahabatan ini terasa murni kekeluargaan." (RS, 64 tahun) 
Lansia juga membina hubungan yang bersifat jarak jauh. Bagi mereka, jarak dapat diatasi dengan komunikasi yang rutin dan komitmen untuk menjalankan reuni paling tidak setahun sekali.

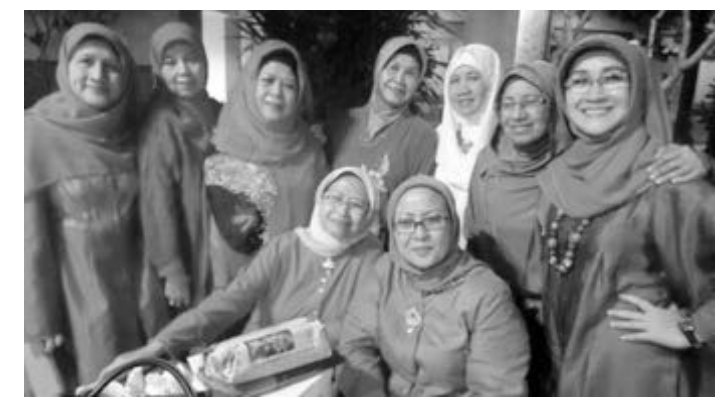

Gambar 10. Jarak Jauh Tidak Melunturkan Persahabatan

"Pertemuan reuni dengan teman-teman seangkatan FKG Unair. Pertemuan yang jarang bisa dilakukan karena tinggal berjauhan, hanya setahun sekali. Tampaknya pertemuan reuni setiap tahun harus rutin dilakukan selama kesehatan masih memungkinkan." (HN, 63 tahun).

\section{Manfaat persahabatan}

Partisipan memiliki beragam pendapat dan juga pengalaman terkait dengan manfaat persahabatan bagi kesejahteraan psikologis dan kesehatan fisik.

\section{$\underline{\text { Energizer }}$}

Partisipan memandang bahwa sahabat mampu membuat mereka menjadi lebih semangat dan bergairah dalam menjalani kehidupan. Sahabat adalah sosok yang selalu menghibur. Aktivitas yang dijalankan dengan semangat selalu menambah keceriaan di usia lanjut. Teman adalah motivator yang menumbuhkan semangat hidup. Hal ini memberikan dampak pada peningkatan kesehatan jiwa dan juga raga.

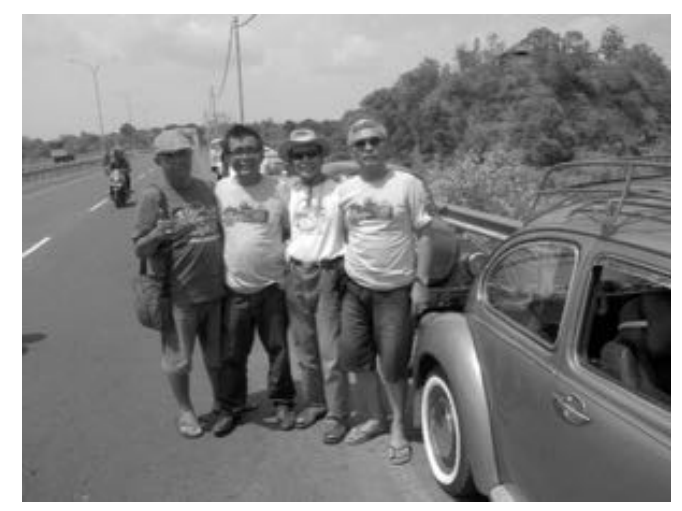

Gambar 11. Vitamin Bagi Kesehatan Jiwa

"Tour yang menyenangkan bersama sahabat. Menikmati kebersamaan, lepas dari rutinitas sehari-hari bersama dengan sahabat. Pastinya merupakan kegiatan yang sangat 
bermanfaat dan menyenangkan. Vitamin buat kesehatan jiwa. Persahabatan terbentuk lewat hobby." (SD, 64 tahun)

Bergaul dengan banyak teman, membuat hidup mereka menjadi lebih bersemangat. Memperluas pergaulan dengan generasi yang lebih muda dan juga cucu ternyata mampu menjadi sumber semangat dan gairah hidup.

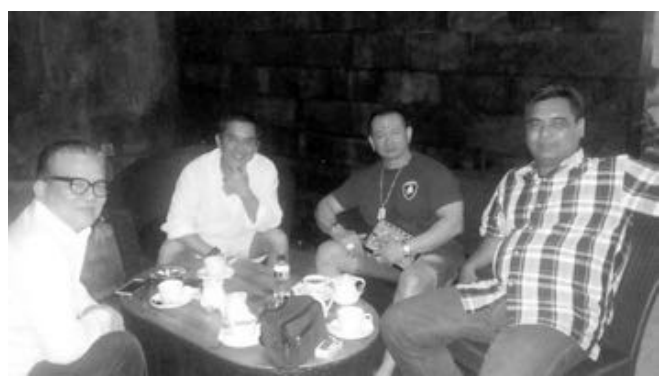

Gambar 12. Semangat Hidup

"Saya melihat bersahabat dengan orang-orang yang lebih muda dan energik sangat memengaruhi semangat kita untuk bisa mengimbangi. Dan yang terjadi adalah sebuah penghargaan apabila kita bisa berkolaborasi dengan jalan pikiran mereka tanpa mengesampingkan pendapat kita sendiri." (CH, 64 tahun).

Sering mengikuti kegiatan yang dilakukan bersama dengan sahabat, mampu menjaga kesehatan dan juga semangat.

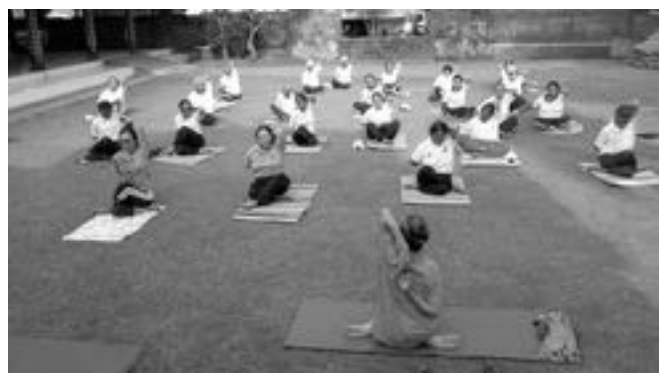

Gambar 13. Kebersamaan dalam Yoga

"Berkumpul untuk kegiatan yang bersifat positif. Senantiasa berbagi ilmu kepada orang lain. Di dalam kehidupan kita memerlukan kebersamaan. Dengan kepedulian dan aktif mengikuti acara di luar, kita tetap sehat dan semangat. Tetaplah berbagi." (KS, 64 tahun) 


\section{$\underline{\text { Membantu dalam Menyelesaikan Masalah }}$}

Sahabat juga dilihat sebagai sosok yang mampu membantu dalam penyelesaian masalah. Sharing yang dilakukan dengan sahabat merupakan sarana untuk membantu dalam penyelesaian permasalahan yang sedang dihadapi. Kebersamaan dengan sahabat mampu mengubah suasana hati yang penuh dengan beban berat menjadi lebih ringan.

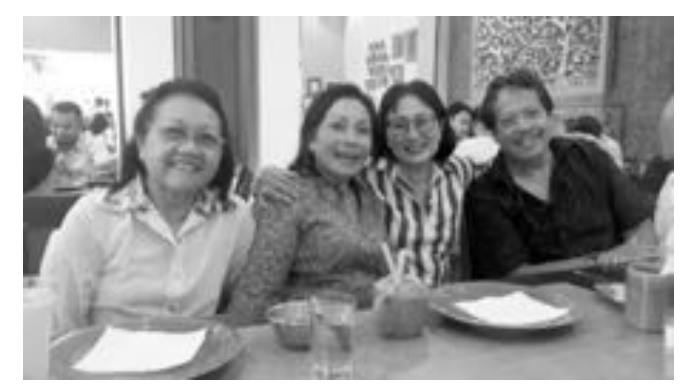

Gambar 14. Sharing dalam Penyelesaian Masalah

"Kebersamaan sebagai wujud dari kedekatan hati dan perasaan kita. Dengan kebersamaan ini suasana hati kita akan berubah dan beban berat akan terasa lebih ringan, malahan dengan sharing sangat membantu sekali dalam penyelesaian masalah kita. Situasi ini ada karena kebersamaan dan ada suatu ikatan energi yang sama di antara kita." (DP, 65 tahun)

Lansia pun masih mampu melakukan diskusi ringan dengan sahabat dalam rangka saling belajar dari pengalaman masing-masing terkait dengan kehidupan yang sudah dijalani.

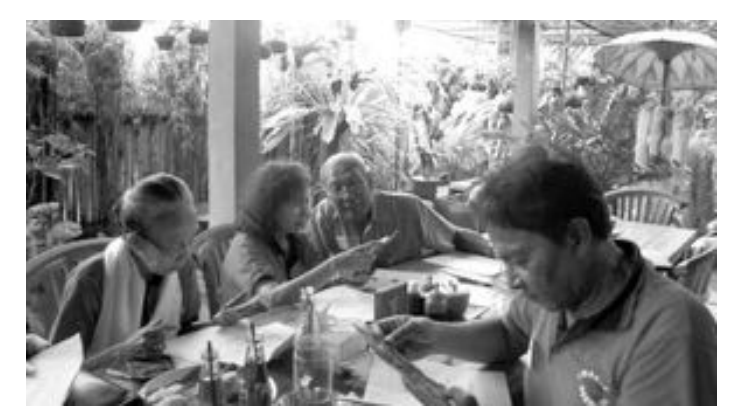

\section{Gambar 15. Diskusi Ringan}

"Bersama teman-teman berdikusi dan makan. Membahas hal-hal yang disampaikan dengan rileks dan santai tanpa ada beban pikiran, semua saling mengisi. Dengan rileks dan disambi makan akan meningkatkan kesejahteraan psikologis dan kesehatan fisik. Dengan tetap sehat fisik dan mental, kebersamaan ini akan tetap eksis." (SM, 70 tahun). 


\section{$\underline{\text { Role Model }}$}

Bagi lansia, persahabatan di usia lanjut memberikan dampak positif, di mana sesama teman dapat menjadi role model dan juga memberikan contoh tentang nilai-nilai kehidupan. Kegiatan yang dilakukan bersama dengan sahabat mampu meningkatkan kepedulian terhadap teman yang sakit. Empati dan support senantiasa diberikan agar teman lebih tabah serta kuat dalam menjalani kehidupan.

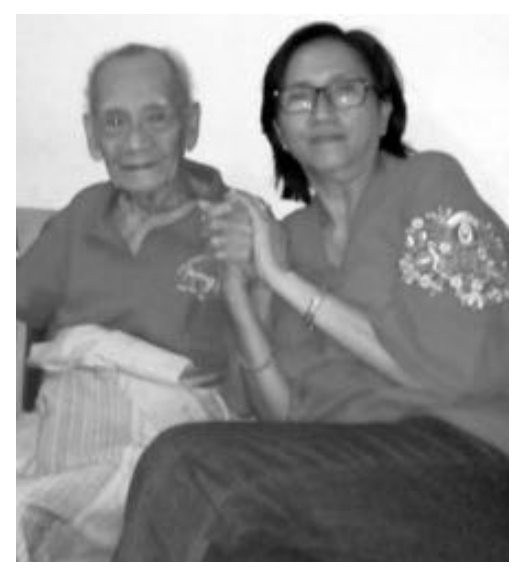

Gambar 16. Empati dan Support

"Rasa empati kepada sahabat dan sekaligus memberikan support agar tabah dan kuat dalam menghadapi sakit tersebut. Ke depannya bentuk persahabatan seperti ini harus dilanjutkan." (AT, 65 tahun).

Dengan diskusi-diskusi yang dilakukan bersama, sahabat mampu menjadi fasilitasi pengenalan diri, kepedulian, dan sensitivitas diri sendiri dan juga teman. Teman merupakan sumber aspirasi dan juga hiburan. Pengalaman-pengalaman yang dilalui oleh teman juga merupakan sumber inspirasi dan memberikan hiburan pada diri lansia.

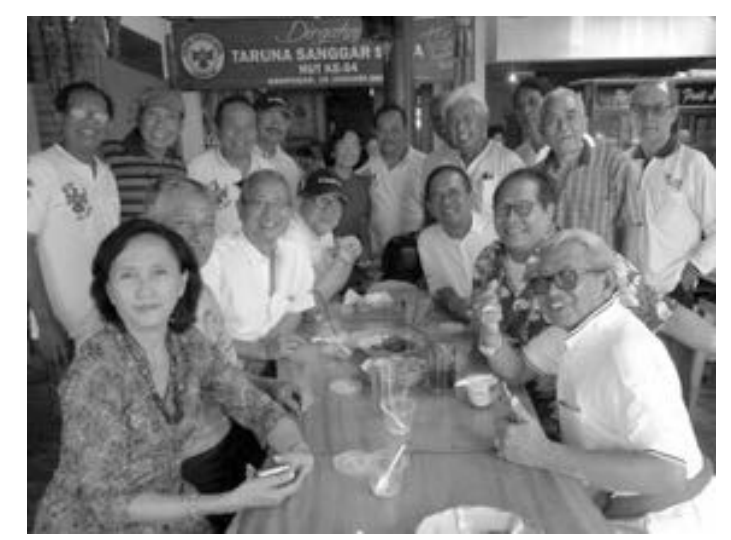

Gambar 17. Meningkatkan Kepedulian dan Sensitivitas

"Reuni para sahabat dan menghadiri ulang tahun sahabat mampu membangun silaturahmi penuh canda. Kegiatan ini adalah kegiatan yang sangat positif, bagus untuk semangat 
hidup sekalian kesempatan belajar menambah kepedulian dan sensitivitas mengenai diri sendiri dan teman. Karena kita dalah mahluk sosial dan berkumpul bersama teman-teman selalu menyenangkan. Komunikasi sebaiknya dijaga." (SD, 64 tahun).

\section{Merasa Lebih Muda}

Sahabat adalah bagian dari sejarah masa lalu. Sahabat di masa-masa sekolah mampu mengembalikan memori indah di masa lalu. Hal ini membuat lansia merasa selalu muda atau lebih muda dari umur yang sesungguhnya. Persahabatan di usia tua mampu menahan penuaan.

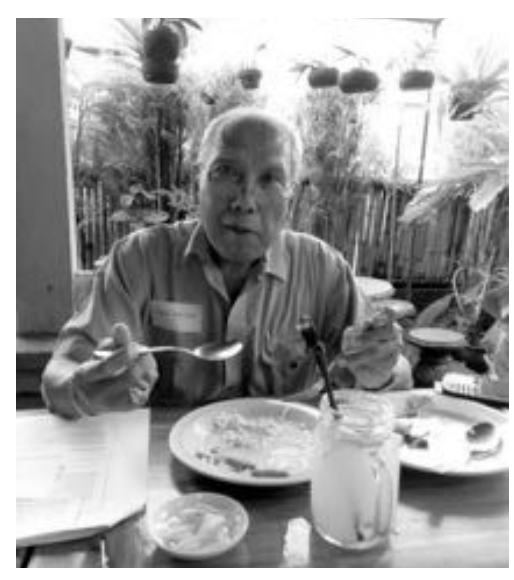

Gambar 18. Nafsu Makan Meningkat dan Menahan Penuaan

"Karena persaudaraan, sesama tua terasa muda lagi. Gairah makan pun berselera. Secara tidak langsung menambah energi dan menahan sel-sel tubuh menua." (RS, 65 tahun).

\section{Sumber Penghargaan}

Hubungan persahabatan yang dibina dengan generasi yang lebih muda, pada dasarnya mampu membuat lansia menjadi lebih merasa dihargai oleh generasi selanjutnya. Lansia merasakan bahwa lansia mendapatkan tempat untuk berdiskusi dan juga berbicara. Pola pikir mungkin boleh beda, namun anak muda rata-rata dapat mendengarkan dan menghargai pendapat mereka. Lansia merasa bahwa pengetahuan dan pengalaman yang mereka miliki dapat menjadi masukan dan juga bentuk perhatian untuk kesejahteraan generasi selanjutnya.

\section{Kegiatan Yang Bermanfaat Bagi Lansia}

Beberapa kegiatan yang dirasakan mampu memberikan manfaat bagi kesejahteraan psikologis dan kesehatan fisik lansia dapat dibagi menjadi bentuk kegiatannya dan sifat tertentu yang mampu memberikan manfaat positif bagi kondisi psikologis dan kesehatan fisik lansia. 
Bentuk kegiatan yang biasa dijalankan lansia bersama dengan teman yang mampu meningkatkan kesejahteraan psikologi dan kesehatan fisik adalah reuni, berdiskusi dan berbagi pengalaman serta ilmu, menjenguk teman yang sakit, menghadiri acara-acara penting sahabat, menjalankan hobby bersama, dan juga aktivitas fisik olahraga. Aktivitas fisik olahraga di antaranya adalah yoga, tracking, dan menari.

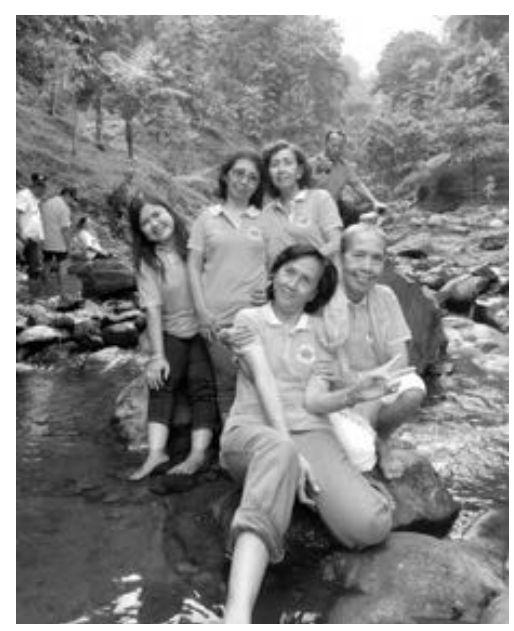

Gambar 19. Tracking Bersama

"Rekreasi bersama dengan sahabat. Istirahat sejenak di sungai. Persahabatan mampu meningkatkan kesejahteraan psikologis dan juga kesehatan fisik." (KT, 64 tahun)

Sifat yang harus dipupuk dan dimiliki oleh lansia agar kegiatan bersama dengan teman mampu memberikan manfaat fisik dan psikologis adalah keterbukaan, kesediaan untuk bertukar informasi, senantiasa membuka komunikasi, empati, kepedulian, serta silaturahmi.

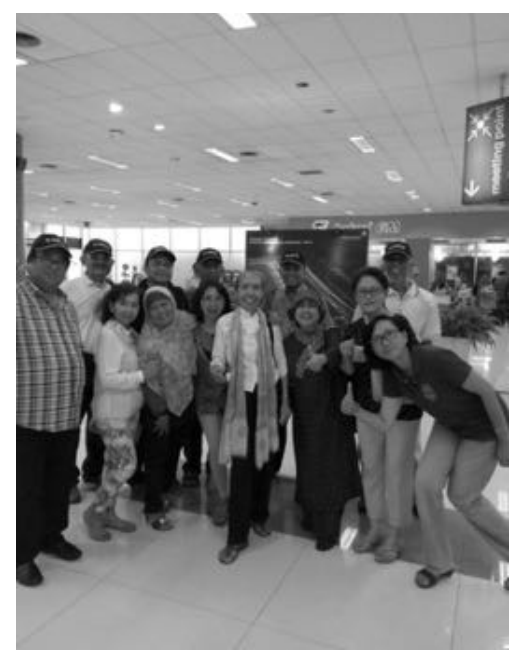

Gambar 20. Bersahabat dan Berkomunikasi

"Teman yang sudah lama tidak bertemu, foto bersama di Bandara Soekarno-Hatta. Sangat menggembirakan. Karena kami bersahabat dan saling berkomunikasi." (KR, 64 tahun) 
Selain itu hubungan persahabatan yang dibina dengan keluarga membutuhkan kepedulian dan kesediaan untuk menyempatkan diri berinteraksi menemani anggota keluarga lainnya sesibuk apa pun kegiatan keseharian. Aktivitas yang dilakukan bersama haruslah senantiasa dilakukan dengan ketulusan. Pada dasarnya lansia harus mampu menjadi role model bagi generasi selanjutnya.

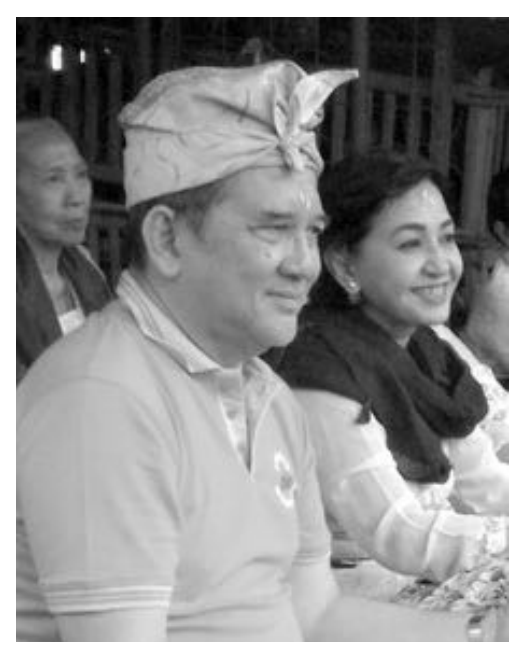

Gambar 21. Ketulusan

"Sesibuk apapun pasti menyempatkan untuk mendampingi pasangan hidup. Hal ini terjadi karena ketulusan hati tanpa paksaan. Ini karena kami fokus selama 50 tahun tetap bersama dan persahabatan ini kami bina terus menerus untuk dijadikan contoh oleh anak cucu ke depan." (CH, 64 tahun)

\section{DISKUSI}

\section{Makna Persahabatan di Usia Lanjut}

Persahabatan didefinisikan sebagai hubungan interdependence yang bersifat sukarela antara dua orang dalam jangka waktu yang lama, untuk memfasilitasi tujuan sosial dan emosional kedua belah pihak, dan di dalamnya mengandung berbagai tipe serta derajat kebersamaan, initimasi, afeksi, dan mutual assistance (Hays, dalam Demir \& Ozdemir, 2010) Melalui definisi ini, terlihat bahwa kebersamaan, kasih saying, atau afeksi adalah komponen penting dari persahabatan. Hal ini sejalan dengan makna persahabatan yang dirasakan oleh lansia pada penelitian ini. Selain kebersamaan dan kasih sayang, persahabatan juga dipersepsikan memiliki makna keterbukaan dan trust.

Galupo dan Gonzales (2013) menyatakan bahwa ada tiga nilai-nilai umum yang berlaku di dalam pertemanan, yakni rasa percaya dan kejujuran, penghargaan kepada teman, dan rasa membutuhkan 
satu dengan yang lain. Pada dasarnya, setiap manusia memiliki kebutuhan untuk dekat dan terikat satu dengan yang lain. Konsep relatedness merupakan kebutuhan psikologi dasar manusia. Pemenuhan akan keterikatan ini adalah hal yang mutlak dalam membangun kualitas persabahatan yang kemudian mampu meningkatkan kebahagiaan individu (Demir \& Ozdemir, 2010). Partisipan dalam penelitian ini juga melihat bahwa persahabatan memiliki makna keterikatan satu teman dengan teman yang lainnya. Keterikatan ini selalu dijaga dalam bentuk silaturahmi. Silaturahmi adalah konsep indigenous yang berarti mengembalikan hubungan masa lalu yang terputus. Dalam konteks ini, persahabatan di usia lanjut dipandang sebagai bagian dari sejarah kehidupan partisipan.

Persahabatan adalah bagian penting dari setiap bagian kehidupan. Persahabatan menghadirkan kebersamaan, berbagi, dukungan emosional di masa sulit, identitas diri, dan bagian dari sejarah (Papalia, Sterns, Feldman, \& Camp, 2007). Konsep reciprocity juga tampak dalam hasil penelitian. Persahabatan memiliki makna perhatian kepada orang-orang terdekat. Ketika lansia memberikan perhatian kepada sesama lansia, perilaku tersebut dilakukan dengan tujuan mendapatkan timbal balik yang sama. Menjenguk teman yang sakit dilakukan dengan harapan, saat sakit dan juga kesepian, teman-teman akan datang dan memberikan bentuk penghiburan yang sama. Grundy dan Sloggett (dalam Gray, 2009) menegaskan bahwa lansia seringkali mempertukarkan dukungan sosial. Mereka mampu memberikan dukungan sosial sebaik mereka mampu menerima dukungan sosial.

\section{Bentuk Persahabatan di Usia Lanjut}

\section{Siapa Sahabat Bagi Lansia}

Dukungan sosial sangat diperlukan di usia lanjut. Seiring dengan bertambahnya usia, interaksi sosial semakin berkurang. Lansia mendapatkan kepuasan dalam hubungan melalui jejaring sosial yang lebih kecil. Walaupun secara frekuensi dan kuantitas berkurang, namun kontak sosial yang dibangun mampu meningkatkan kesejahteraan psikologis mereka (Lansford, Sherman, \& Antonucci, dalam Papalia dkk., 2007). Social Convoy Theory menjelaskan bahwa lingkaran luar pertemanan pada usia lanjut akan berkurang, yang tersisa adalah teman yang memiliki derajat kebersamaan dan intimasi. Sahabat dekat dan keluarga adalah salah satu dari kelompok teman dengan derajat kebersamaan dan intimasi yang tinggi.

Keluarga mampu menghadirkan bentuk dukungan sosial yang signifikan bagi kesejahteraan usia lanjut (Papalia dkk., 2007). Dalam penelitian ini, terlihat bahwa keluarga, seperti pasangan, anak, dan cucu, mampu menjadi sahabat bagi usia lanjut. Keluarga memberikan dukungan baik yang bersifat fisik 
maupun material. Wenger, Burholt, dan Scott (dalam Gray, 2009) mengungkapkan bahwa keluarga berperan dalam personal care dan memberikan umpan balik saat berhadapan dengan personal problem.

Tidak hanya keluarga, Wenger, Burholt, dan Scott (dalam Gray, 2009) juga menemukan bahwa usia lanjut memerlukan teman di luar keluarga sebagi sumber dukungan dan sharing informasi, mengatasi kebosanan, dan sumber semangat yang mampu menjauhkan usia lanjut dari depresi serta kebosanan. Sebagian besar dari kelompok lansia akan mempertahankan persahabatan dan teman-teman yang mereka kenal pada tahap perkembangan sebelumnya, seperti teman-teman di masa sekolah. Temuan ini sejalan dengan socioemotional selective theory yang memandang bahwa usia lanjut memiliki kecenderung untuk berinteraksi dalam konteks persahabatan dengan individu yang sudah mereka kenal (Carstensen, dalam Papalia, dkk, 2007). Atas dasar pendekatan inilah, lansia cenderung membina persahabatan dengan teman yang mereka kenal di masa sekolah atau ketika bekerja.

Blieszner (2014) menyatakan bahwa persahabatan juga dapat dibina dengan teman baru. Menambahkan pendapat Blieszner, Papalia dkk. (2007) melihat bahwa hubungan teman baru dibina jika berkontribusi kepada kebutuhan emosional mereka, salah satu adalah kebutuhan akan penghargaan dan self-esteem. Dalam penelitian ini ditemukan bahwa bersahabat dengan generasi yang lebih muda dapat menghadirkan persahabatan dan kebutuhan akan didengar. Pada akhirnya lansia akan mempertahankan hubungan persahabatan yang bermakna dan cenderung melepaskan hubungan yang tidak memiliki makna yang signifikan bagi lansia (Blieszner \& Roberto; Carstensen, dalam Blieszner, 2014).

\section{Durasi Persahabatan}

Persahabatan pada lansia biasanya sudah dibina sejak lama (Blieszner, 2014). Persahabatan dipandang sebagai sesuatu yang kekal dan langgeng oleh partisipan. Kebersamaan dan hubungan timbal balik yang mutual menjadi lebih intens. Mereka berbagi nilai, minat, dan permasalahan yang sama seperti layaknya keluarga (Blieszner, 2014). Bagi partisipan, persahabatan yang berlangsung lama, membuat sahabat bertransformasi menjadi keluarga. Dalam proses menjalin persahabatan, hubungan yang dibina dalam jangka waktu yang lama, biasanya masuk ke dalam tahapan sustainment, di mana kedekatan emosional menjadi semakin kuat, stabil, dan menetap (Blieszner, 2014). Seperti layaknya hubungan pertemanan lainnya, persahabatan di usia lanjut juga memungkinkan hubungan jarak jauh. Komunikasi yang rutin adalah salah satu cara untuk mempertahankan persahabatan jarak jauh. Johnson dan Troll (dalam Papalia dan kawan-kawan., 2007) melalui penelitiannya mengungkapkan bahwa lansia yang memiliki hubungan pertemanan jarak jauh mampu menggunakan alat-alat komunikasi penunjang dalam mempertahankan kualitas hubungan mereka. 


\section{Manfaat Persahabatan}

Teman adalah sosok yang mampu meningkatkan kesejahteraan psikologis dan juga kesehatan fisik. Secara psikologis, persahabatan mampu menjadi sumber semangat hidup dan kesehatan jiwa. Akin dan Akin (2015) menemukan bahwa persahabatan mampu secara langsung meningkatkan kebahagiaan subjektif. Kebahagiaan subjektif menyangkut meningkatnya afek positif dan menurunnya afek negatif (Seligman, 2005). Afek positif menyangkut kebahagiaan, kegembiraan, dan juga keceriaan. Dalam penelitian ini persahabatan juga mampu menghindarkan individu dari pikiran-pikiran negatif terkait kehidupan.

Cable dan kawan-kawan. (dalam Blieszner, 2014) mengungkapkan bahwa persahabatan mampu meningkatkan pandangan positif terkait kehidupan. Persahabatan juga mampu membangkitkan rasa dihargai dan kompeten dalam melakukan suatu hal tertentu (Demir \& Ozdemir, 2010). Seperti yang diungkapkan oleh partisipan bahwa persahabatan dengan generasi selanjutnya mampu menghadirkan penghargaan dan meningkatkan self-esteem. Persahabatan adalah sumber social support bagi lansia, sahabat adalah sumber informasi dan dukungan dalam penyelesaian masalah yang dihadapi (Gray, 2009; Hemingway \& Jack, 2013). Di samping itu, sesuai dengan uraian Blieszner (2014), kecenderung lansia untuk mempertahankan persahabatan yang bermanfaat secara tidak langsung membuat lansia memilih dalam menentukan siapa yang dinilai sebagai sahabat atau teman. Pendapat ini sejalan dengan teori socioemotional selective theory.

Pada akhirnya, sahabat dipandang sebagai sosok yang mampu menjadi inspirasi dan panutan. Salah satu yang menginspirasi adalah nilai-nilai empati, penghargaan, dan wisdom di usia lanjut. Temuan ini sejalan dengan pendapat Erikson (Papalia dan kawan-kawan., 2007) terkait dengan tahap perkembangan psikososial di usia lanjut yang sudah mencapai tahapan wisdom versus despair.

Selain manfaat secara psikologis, persahabatan juga mampu menghadirkan manfaat berupa peningkatan kesehatan fisik, termasuk kesehatan subjektif. Partisipan menyampaikan bahwa persahabatan membangun persepsi bahwa mereka tidak tua walaupun memasuki usia lanjut. Bagi partisipan, persahabatan mampu menahan penuaan, meningkatkan selera makan, dan penambah energi. Individu dengan kesehatan subjektif yang tinggi biasanya akan memiliki lebih banyak energi ketika berhadapan dengan aktivitas keseharian dan tidak menjadi rentan terhadap stres (Akin \& Akin, 2015). 


\section{Bentuk Aktivitas Yang Bermanfaat}

Kegiatan yang bermanfaat bagi lansia antara lain adalah berkumpul bersama teman, sharing pengalaman, mencari solusi dari masalah yang dihadapi, menjenguk teman, menghadiri acara penting sahabat, menjalankan hobby, dan juga melakukan aktivitas fisik. Konsep reciprocity dalam persahabatan mampu menjadi dasar bagi pembentukan kegiatan yang berguna bagi lansia (Gray, 2009). Selain itu, kegiatan yang dilakukan juga mampu menghadirkan relatedness, kemandirian, dan juga menghadirkan perasaan kompeten bagi lansia. Relatedness, kemandirian, dan rasa kompeten adalah kebutuhan psikologis dasar yang dapat dipenuhi melalui persahabatan (Demir \& Ozdemir, 2010).

Bentuk kegiatan seperti reuni, berbagi pengalaman dan masalah, menjenguk teman, dan menghadiri acara penting sahabat adalah bentuk kegiatan yang mampu menghadirkan kebersamaan. Menjalankan hobby dan juga aktivitas fisik bersama seperti tracking, yoga, dan menari mampu menjawab kebutuhan akan kemandirian dan juga rasa kompeten secara fisik. Menjalan aktivitas fisik bersama dengan sahabat menjadi faktor penting dalam menumbuhkan kepedulian untuk terlibat dalam aktivitas fisik pada lansia. Capalb, O’Halloran, dan Liamputtong (2014) menemukan bahwa lansia yang memiliki teman yang ikut dalam program aktivitas fisik bersama-sama, keanggotaannya akan bertahan lebih lama pada satu klub kebugaran yang diikuti.

Kegiatan di atas mampu menghadirkan manfaat positif saat kualitas persahabatan dijaga. Beberapa komponen dari kualitas persahabatan adalah kebersamaan, keinginan untuk menolong, kedekatan, dan juga self-validation (Demir \& Ozdemir, 2010) Kebersamaan dan kedekatan dapat dibina dengan senantiasa menjalin komunikasi dan berbagi informasi bersama dengan sahabat. Pendapat ini sejalan dengan yang diungkapkan oleh Blieszner (2014), yaitu kegiatan dan interaksi persahabatan akan berdaya guna di saat komunikasi dan pertukaran informasi selalu dijaga oleh lansia, adanya ketulusan serta mutual trust, dan kesiapan untuk saling berbagi. Sejalan dengan perkembangan psikoseksualnya, maka lansia pun harus menjadi contoh bagi generasi selanjutnya. 


\section{SIMPULAN DAN SARAN}

\section{Simpulan}

Persahabatan di usia lanjut mampu menghadirkan makna kebersamaan, kasih sayang, afeksi, dan juga reciprocity. Bentuk persahabatan di usia lanjut pada dasarnya tidak memiliki perbedaan yang berarti. Perbedaannya terletak pada hal-hal yang dianggap penting dalam persahabatan yang kemudian menjadi dasar bagi pengambilan keputusan untuk mempertahankan persahabatan. Persahabatan pada usia lanjut bersifat lebih selektif dan cenderung mempertahankan hubungan yang langsung memberikan dampak bagi kesejahteraan di usia lanjut. Hubungan biasanya berlangsung lama, bertahuntahun, sehingga mampu mentransformasi sahabat menjadi sosok keluarga. Dalam konteks hubungan kekeluargaan, maka terjadi pertukaran nilai-nilai dan juga pandangan hidup. Sahabat juga mampu menjadi inspirasi dan panutan dalam mencapai tahapan wisdom di usia lanjut. Usia tidak membatasi usia lanjut untuk beraktivitas. Kesediaan untuk menjalankan aktivitas sangat dipengaruhi juga oleh kehadiran teman, contohnya dalam menjalankan aktivitas fisik. Sejauh persahabatan mengandung komponen kebersamaan, mutual trust, reciprocity, dan self-validation, maka persahabatan di usia lanjut mampu berkontribusi bagi kesejahteraan psikologis dan kesehatan fisik di hari tua.

\section{Saran Teoretis}

Penelitian ini memberikan kontribusi pada Ilmu Psikologi, khususnya Psikologi Perkembangan dan Psikologi Gerontologi dalam hal menjelaskan mengenai perkembangan usia lanjut dan usaha-usaha promotif yang dapat dilakukan untuk mempertahankan kesehatan serta produktivitas di usia lanjut. Penelitian yang melibatkan lansia sebagai populasinya dapat mempertimbangkan pendekatan kualitatif dengan menggunakan photovoice untuk menggali pengalaman, sikap, dan tingkah laku lansia terkait dengan bidang yang ingin diteliti.

\section{Saran Praktis}

Berdasarkan temuan di atas, maka beberapa critical finding yang dapat digunakan bagi perencanaan model manajemen kesehatan bagi lansia antara lain: (1) Usia bukan menjadi ukuran dalam membina persahabatan; (2) Konsep reciprocity menjadi hal yang penting untuk ditanamkan di usia lanjut, di mana lansia memiliki kemampuan untuk memberikan bantuan sebaik kemampuan 
mereka dalam menerima bantuan; (3) Perasaan kompeten dan mampu berkontribusi bagi generasi selanjutnya dapat dijadikan dasar bagi pembentukan kegiatan intergenerational; dan (4) Aktivitas fisik yang disiapkan bagi usia lanjut sebaiknya menghadirkan teman sebaya yang mampu mendorong usia lanjut untuk aktif dan bersemangat.

\section{REFERENSI}

Akin, A., \& Akin, U. (2015). Friendship quality and subjective happiness: The mediator role of subjective vitality. Education and Science, 40(177), 233-242. DOI: 10.1539/EB.2015.3786

Blieszner, R. (2014). The worth of friendship: Can friends keep us happy and healthy? Journal of The American Society on Aging, 38(1), 24-30.

Capalb, D. J., O’Halloran, P., \& Liamputtong, P. (2014). Why older people engage in physical activity: An exploratory study of participants in a community-based walking program. Australian Journal of Primary Health, 20, 74-78.

Demir, M., \& Ozdemir, M. (2010). Frienship, need satisfaction, and happiness. Journal of Happiness Study, 11, 243-259. DOI: 10.1007/s10902-009-9138-5

Galupo, M. P., \& Gonzales, K. A. (2013). Friendship values and cross-category friendships: Understanding adult friendship patterns across gender, sexual orinetation, and race. Journal of Sexual Roles, 68, 779-790.

Gray, A. (2009). The social capital of older people. Ageing and Society, 29, 5-31.

Hemingway, A., \& Jack, E. (2013). Reducing social isolation and promoting well-being in older people. Quality in Ageing and Older Adults, 14(1), 25-35.

Lestari, M. D. (2015). Self-perception of aging, sexual quality of life, happiness, and autonomy among middle and late adulthood women in Denpasar. Journal of Indian Academy of Geriatric, 11, 25-26.

Lestari, M. D. (2016). Menuju Denpasar yang ramah lansia. Scientific News Magazines. Ditemu kembali dari https://scimag.unud.ac.id/posts/menuju-denpasar-ramah-lansia. 
O'Grady, L. (2008). The world of adolescence: Using photovoice to explore psychological sense of community and well being in adolescents with and without an intelectual disability (Disertasi tidak dipublikasikan). Victoria University, Australia.

Papalia, D. E., Sterns, H. L., Feldman, R. D., \& Camp, C. J. (2007). Adult development and aging (3rd ed.). New York, NY: The McGraw-Hill Companies.

Seligman, M. E. P. (2005). Authentic happiness. New York, NY: Free Press.

Strauss, A., \& Corbin, J. (1990). Basic of qualitative research: Grounded theory procedure and techniques. California: Sage Publications, Inc.

Suardiman, S. P. (2011). Psikologi usia lanjut. Yogyakarta, Indonesia: Gadjah Mada University Press. 